\title{
An Exploratory Qualitative Study of Brand Associations as a means for Brand Extensions: Part 2
}

\author{
H Kasper \& Y Strepp \\ Marketing Department, Maastricht University, The Netherlands \\ N S Terblanche \\ Dept of Business Management, University of Stellenbosch
}

\begin{abstract}
One of the more familiar means to capitalise on the reputation of an established brand, is to use the brand name to introduce new products in a different product category. Various factors impact on the extent to which brand extensions can benefit from or even detract from the original brand. The focus of this study is on brand associations as means to extend the original brand. A qualitative study, in contrast with the quantitative nature of most earlier studies, was used to elicit an unbiased picture of consumers' associations of a brand. The use of a qualitative study also made it possible to follow up on and probe the comments made by respondents. The study examined consumers' reactions to a variety of fictitious extensions for four different popular brands (Coca-Cola, Benetton, Yamaha, and Kellogg's). The key rationale for this study was to observe how consumers' associations of a brand impact on their evaluation of extensions to that brand. Six propositions were investigated. Because of the considerable extent of the findings generated by the qualitative approach, the research is reported in two parts. The findings on three propositions were reported in Kasper, Strepp and Terblanche (2005). The findings on the remaining three propositions are described in this second part of the reported research.
\end{abstract}

Keywords Brand extensions, Brand associations, Qualitative study

JEL M31

\section{Introduction and theoretical framework}

The background to this study is dealt with comprehensively in Kasper, Strepp and Terblanche (2005). This section will briefly attend to the rationale of the study and the salient characteristics of the theoretical framework underlying the study.

Brands are complex and can perform a variety of functions for both the consumer and product or service provider (Kasper, Van Helsdingen \& De Vries, 1999). In an extensive study by Bottomley and Holden (2001), it was found that the fit between the parent brand and the extension categories, and the interaction of the two are not the same across brands and cultures when consumers evaluate brand extensions. The focus in this study is on the impact of brand associations on brand extensions.

Consumers use a brand as a tool of selfexpression and a marketer has to take this relationship into account when the extension of a specific brand is considered. The transfer of specific brand associations to brand extensions has been researched extensively (Swaminathan, Fox \& Reddy, 2001; Glynn \& Brodie 1998; Aaker \& Keller, 1990; Park, Milberg \& Lawson, 1991; Broniarczyk \& Alba, 1994). Ideally, associations with the original brand should benefit the brand extension; however, brand associations may also impact negatively on the extension (Aaker \& Keller, 1990). 
Four major brands, Coca-Cola, Benetton, Yamaha, and Kellogg's, were selected to test the impact of brand associations on brand extensions empirically and explore to what extent and in what way brand associations play a role in the evaluation of brand extensions. We make the assumption that consumers have diverse associations with the brands examined in this study. A qualitative study, compared to the more popular quantitative approach, was used to elicit an unbiased picture of a consumer's associations of a brand (Fournier, 1998).

\section{2}

\section{Propositions}

In branding, it is possible to differentiate between two main types of products: products with a function-oriented brand image and products with a symbolic brand image (Low \& Lamb Jr, 2000). Some authors, e.g. Pitta and Katsanis (1995), prefer a somewhat different concept of product grouping, differentiating between products with a function-oriented brand image, and products with a prestigeoriented brand image. Accordingly, functionoriented products are characterised by unique aspects related to product performance (e.g. computer software), whereas prestige-oriented brands are visualised primarily in terms of a customer's expression of self-image (e.g. luxury watches or cars) (Pitta \& Katsanis, 1995).

In this study, we differentiate between functional and symbolic brands, because we do not want to limit the study to the kind of symbolic brands that convey an image of prestige. There are many brands in today's world that trigger strong symbolic associations without necessarily being considered luxurious or prestigious. Especially for young people, brands are often a means to express their values and beliefs, or to follow set trends. If a young girl for example uses products from "The Body Shop", she might want to demonstrate that she is supportive of the environmentally friendly production policy the company has. Hence, the brand "The Body Shop" has a strong symbolic value, but is not considered prestige-oriented in the common sense at all.
According to the study conducted by Bhat and Reddy (1998: 33), "functional brands satisfy immediate and practical needs", whereas "symbolic brands satisfy symbolic needs such as those of self-expression and prestige". In other words, it is assumed that consumers' needs may be classified as being either functional or symbolic in nature. Functional needs are related to specific and practical consumption problems, whereas symbolic needs refer to self-image and social identification (Bhat \& Reddy, 1998). As a result of their research study, the two authors found that functionality and symbolism are distinct concepts that do not really represent two ends of a brand concept continuum, i.e. it is possible to have brands that have functional as well as symbolic meanings for customers. A Mercedes car, for example, has both symbolic value (prestige, status, etc.) and functional value (safety, speed, etc). It might be difficult to find any kind of brand that has "only" symbolic value, because consumers will rarely buy products that satisfy no real functional need. If for instance a consumer buys a Rolex watch for several thousands of rands, he most probably does so because he regards a Rolex watch as a kind of status symbol. Thus, the watch has certainly strong symbolic value, and conveys a prestige-oriented image. That, however, does not imply the consumer's indifference about whether the watch works properly; the functionality of the watch is also important to him.

Therefore, when we speak of symbolic brands in this study, we mean brands that clearly have a strong symbolic meaning, in addition to functional features, e.g. a Rolex watch. Functional brands on the other hand, include brands that either have no symbolic value at all (e.g. Paracetamol headache medication), or brands whose symbolic value is generally much less important than its functionality (e.g. Lipton tea).

When a company considers launching a new extension of a brand, the difference between symbolic and functional brands may play an important role. We have previously assumed that various associations consumers have with a brand have a strong impact on consumers' buying decisions. We have further suggested that 
associations and beliefs about a brand can be transferred to new brand extensions. If this holds, we can assume that symbolic brands, in contrast to functional brands, allow for brand extensions that are very dissimilar from the original product that the brand name stands for. The idea behind this assumption is that symbolic brands trigger brand associations, which are very broad and not limited to a certain product category. For example, if consumers associate Coca-Cola with young, attractive people who enjoy parties and having fun (the image often portrayed in Coca-Cola commercials), these associations might be transferred to other products that fit with this particular image. Within this perspective, the company could for instance use these associations when launching snack food such as crisps, peanuts, or popcorn with the name Coca-Cola. Even though these products are not directly related to soft drinks, people may see the link because of various associations they have with the name Coca-Cola.

For primarily functional brands, stretching the brand into different product categories may be more difficult because the lack of symbolic associations limits the selection of extension products that may be acceptable to consumers. Consumers may have great trust in a company to produce one specific functional product. This confidence, however, may vanish as soon as the company launches an extension of the brand that has no relation to the core product at all. For example, a consumer may believe that Parker produces the best roller pens on the market. This does not necessarily mean that he or she would buy a Parker microwave oven if it appeared on the market as a technically perfect new brand extension. There is simply no link neither functional nor symbolic - between the Parker pen and the Parker microwave oven. Based on the assumptions previously discussed, we suggest the following proposition:

P1: Symbolic brands generally allow for a wider stretching than functional brands if the extension product fits with the brand image on a symbolic level.

It has been argued that symbolic brands may be more extendable than purely functional brands because consumers typically have a broader range of associations with symbolic brands than with purely functional brands. This, in turn, offers the marketer a wider selection of possible brand extensions that fit with the parent brand, either on a symbolic or on a functional level.

An alternative way of increasing the amount and the diversity of associations consumers have with a brand is to offer a broad product range under one brand name. This implies that a brand has been extended in the past, or that initially several different products were launched under one brand name. One example is Virgin, a company/brand that started in the 1970s as a small mail order record company. Today, the brand name Virgin is associated with various products, including airplanes, trains, soft drinks, music, wines, publishing, and many more. As a result of Virgin's extremely diverse product portfolio and the numerous different associations' consumers have with the brand name Virgin, the brand's extendibility is rendered much easier. In other words, Virgin's broad product portfolio may serve as a strong base or "platform" from which the brand can be extended further and further. For example: Consumers associate the name Virgin with airplanes. The company may "use" these associations to successfully extend the brand into the travel agency industry. At the same time, Virgin is associated with soft drinks, which may help in extending the brand into a related product category, such as fruit juice.

Previous research studies have dealt with the effects of a brand's product portfolio on brand extensions. A research study conducted by DelVecchio in 2000 found that characteristics of a brand's portfolio play an important role in affecting consumers' impressions of brand reliability (the ability of an existing brand to reduce the risk associated with the purchase of a brand extension). In contradiction to prior research indicating that extensions often cause brand dilution, DelVecchio (2000: 457-458) claims that having a great number of products affiliated with a brand has a positive effect on consumers' evaluations of new extensions.

Most researchers have focused on the possibility that brand extension strategies may 
lead to brand dilution as a consequence of changes in the existing brand schema. DelVecchio (2000) counter-argues that these changes may in fact strengthen the strategic position of the brand by creating the foundation for greater acceptance of subsequent changes. This statement is based on the belief that as the number of products affiliated with a brand increases, so does the firm's investment in the brand. When consumers understand the magnitude of the firm's investment and realise its value as a form of collateral, they should have a more favourable attitude towards brands that are associated with a greater number of products (DelVecchio, 2000: 459-460).

Dacin and Smith conducted a similar study in 1994. Using two laboratory experiments, the authors came to the conclusion that there is a positive relationship between the number of products affiliated with a brand and consumers' confidence in their judgment of the quality of a brand extension. Other than DelVecchio (2000) however, Dacin and Smith also found that increased portfolio quality variance diminishes the strength of this relationship (Dacin \& Smith, 1994: 239).

The findings of these two studies on the role of brand portfolio characteristics suggest that having a large number of products in one portfolio can be beneficial for a company for different reasons. First, it shows consumers how much money the company invests in the brand and this will increase their confidence. Second, a strategy of successive extension reduces the effect of fit on subsequent extensions and therefore broadens the domain of future extension opportunities. Consequently, marketers should consider a clear long-term brand extension strategy that both levers and builds a brand's strength. In this context, however, it is very important that a high degree of quality consistency across all products is maintained.

We have argued that the more associations a brand name triggers in terms of products affiliated with the brand, the higher the chances that consumers will accept future extensions. This is because the positive effect of perceived fit between a brand extension and existing products will be achieved more easily (as there are various products the extension may fit with). Moreover, as previous research has shown, a company's increased investment in the brand has a positive effect on consumer confidence. Based on these assumptions, the following proposition is made.

P2: Having an increased number of products affiliated with a brand has a positive effect on consumers' evaluations of a new extension of the brand.

A final aspect of brand extensions that is examined in this research study is the risk of brand dilution. Brand dilution occurs when a brand extension damages the original brand name. One way in which an extension can damage the parent brand name is if it creates undesirable associations. Sunkist, for example, tried to create a health image around its fruit drink product line. It is certainly possible that Sunkist fruit rolls - a candy launched by Sunkist as a brand extension - hurt the Sunkist health image (Aaker, 1990: 52). As mentioned above, some research studies (e.g. Aaker \& Keller, 1990; Loken \& John, 1993) suggest that an extension strategy may lead to brand dilution. These studies argue that as products are added to a brand, the existing brand scheme held by consumers is altered and the brand's strength is compromised.

As previous research has also indicated, the risk that an extension will transfer negative associations to the original brand image differs between various brands. Aaker (1990: 52) found that the transfer of negative associations "is less likely if the original brand associations are very strong, if there is a distinct difference between the original brand and the extension, and if the difference is not so extreme as to be incongruous".

Loken and John (1993) have tried to investigate situations in which brand extensions are more or less likely to dilute beliefs associated with the family brand name. The results of their research reveal that wellestablished brand names may be hurt by certain kinds of brand extensions. In general, extensions delivering attributes that are at odds with what consumers expect from the family brand can result in dilution of specific beliefs associated 
with the family brand name. Furthermore, they find that several factors influence the degree of risk of a brand name being diluted. First, the risk of brand name dilution seems to be greater for brand extensions that are perceived to be moderately typical of the family brand. In contrast, those extensions that were perceived as clearly different from other products with the family brand name carried a more moderate degree of risk. Second, the risk of brand name dilution seems to be stronger for some types of beliefs than others. Research found that beliefs about global and less distinctive attributes such as quality are more immune to dilution than beliefs about very specific and distinctive attributes, for example gentleness or health.

Finally, Loken and John (1993: 81-82) suggested - in contrast to previous research that dilution may not be prevented by launching brand extensions in product categories that are different from those in which the family brand is currently operating. In their study, similarity between the extension and family brand category was not a strong determinant of brand dilution.

In our study, we have focused on the impact associations that a brand has on the evaluations of brand extensions. The study suggests that product-specific associations, as well as quality and symbolic associations, may be transferred from a brand to a brand extension. Consequently, these associations may be either helpful or harmful to the success of the extension. We assume that the same holds in the opposite way for "new" associations triggered by the extensions. In other words, various kinds of associations consumers have with a brand extension may be transferred back to the parent brand. As a result, they may either strengthen the original brand and its image, or they may create undesirable beliefs that are at odds with existing associations with the parent brand, and consequently cause brand dilution. This leads us to proposition three.

P3: If associations consumers have with a brand extension are at odds with what they associate with the parent brand, the risk of brand dilution is high.

\section{Overview of the method of the study}

As mentioned earlier, we studied consumers' reactions to a variety of fictitious extensions for four different popular brands (Coca-Cola; Benetton; Yamaha; Kellogg's). The focus of this study is to explore the ways associations consumers have with a brand name influence the way they evaluate brand extensions, and to what extent a brand extension can differ from the original core product and still be accepted by consumers. The qualitative study enabled us to probe and follow-up interviews to uncover and explore underlying motivations, beliefs, attitudes and feelings.

Brand stretching may be defined as transferring a successful brand name to quite different products and markets; an example in this regard would be where a marketer uses an established brand name to enter new markets which might be completely unrelated to the original product market (Doyle, 1994). The smaller sample of respondents produced more detailed customer information as this approach enabled us to explore consumer sentiments in more depth than would have been possible with quantitative data. In the context of this study, respondents' explanations of what they thought of the various products was crucial and helped us gain knowledge and understanding about the psychological factors underlying consumers' evaluations of brand extensions.

To gain a deeper understanding of the actual factors underlying consumers' reactions to brand stretching, respondents were firstly asked to freely express all the associations they had with a specific brand name. Secondly, respondents were introduced to different fictitious extensions of the brand, and had to say how likely they were to buy the product, and furnish reasons why they would or would not buy the product. The problem of brand dilution as a potential hazard of brand extensions was dealt with by asking respondents whether the extension would change their attitude toward the original brand, and in what way (positive or negative). 


\section{4}

\section{Study participants}

As stated in Kasper, Strepp and Terblanche (2005) a convenience sample of 38 postgraduate students was used. In view of the fact that the scope of the full questionnaire - with all four brands - was very large, respondents were given the choice of selecting the brands they wished to give their opinions about. In total, the following number of questionnaires was received for the four well-known brands:

$\begin{array}{ll}\text { Coca-Cola } & : 25 \text { respondents } \\ \text { Benetton } & : 22 \text { respondents } \\ \text { Yamaha } & : 21 \text { respondents } \\ \text { Kellogg's } & : 21 \text { respondents }\end{array}$

\section{5}

\section{Motivation for the brands selected for the study}

The four brands used in this study - Coca-Cola; Benetton; Yamaha; Kellogg's - were selected on the following criteria:

- Well known and at least to some regard, relevant to or used/consumed by the respondents;

- the brands are from diverse countries of origin, namely American, Japanese and European;
- the brands represent functional and symbolic brands;

- some of the brands have been extended in the past;

- it was expected that the brands could elicit relatively specific associations as they are all well established and have been on the market for a long time; and

- the brands belong to different product categories in order to gain more results that could be generalised.

The brands selected represent functional and symbolic brands. The 12 fictitious brand extensions (three per brand) were selected to be reasonable and not irrational, but had to provide diversity with regard to their fit with the original brand. Extensions were thus chosen so that some were more "fitting" than others. The purpose was to obtain results that could provide certain guidelines/measures as to how far a brand can really be stretched. Other extensions were chosen with the intention that there is absolutely no link to the brand's original product, and therefore appear to be far-fetched at first sight. The purpose is to determine how consumers respond to these brand extensions. Table 1 illustrates the selected brands, their extensions and expected fit.

\section{Table 1}

Selected brands and extensions suggested to participants

Brand extension

\begin{tabular}{|l|l|l|l|l|}
\hline \multicolumn{1}{c|}{ Degree of fit* } & Good fit & Moderate fit & No fit \\
\cline { 2 - 5 } & Coca-Cola & Beer & Airline & Computer hardware \\
\cline { 2 - 4 } & Benetton & Magazine & Electronic devices & Chewing gum \\
\cline { 2 - 4 } & Yamaha & & Furniture Internet shop & Sunscreen \\
\cline { 2 - 5 } & Kellogg's & Microwave dinners & Hotel chain & Bicycle \\
\cline { 2 - 5 } & &
\end{tabular}

* Based on the authors' perceptions. 


\section{6}

\section{Measurement and data collection}

A questionnaire was developed to gather data to deal with the propositions formulated above. Before the questionnaire was used in the personal interviews conducted in South Africa and e-mailed to the respondents in Europe, the items were subjected to a pilot study to ensure the face validity thereof. The questionnaire included both open-ended questions and closed scale questions. Additional open-ended questions were asked to elaborate on replies to certain scale questions.

Two different kinds of interval scales were used to collect the data. A 7-point numerical scale measured the respondents' acceptance of a specific brand extension, where 1 signified definitely no and 7 signified definitely yes. The same interval scale was used for those questions that required a yes/no response, indicating a particular degree of affirmation or negation. The second type of scale that was used in the study is an 11-point numerical scale ranging from -5 to 5. In this regard, respondents were required to express negative or positive feelings, or they could mark 0 when they had a neutral attitude. The purpose of the study was described to the respondents and the term brand extension was explained to those respondents who were unfamiliar with it. Respondents were given unlimited time to answer the questions addressed to them; they were, however, encouraged to give certain answers spontaneously.

\section{7}

\section{Discussion and implications of the major findings}

Proposition 1 suggests that symbolic brands allow for a wider stretching than primarily functional brands if the extension product fits with the brand's image on a symbolic level. In our study, we have identified Coca-Cola and Benetton as primarily symbolic brands, Yamaha as a primarily functional brand, and Kellogg's as a brand that has strong functional value, but at the same time triggers symbolic and emotional associations. Regarding the question of how far a brand may be stretched, we used all respondents' acceptance of each extension, computed an average score, and used the resulting score as an indicator for the possible success of the particular product. Table 2 provides a ranking of the average acceptance scores.

\section{Table 2}

Ranking of average acceptances of brand extensions

\begin{tabular}{|c|l|c|}
\hline Rank & Brand extension & $\begin{array}{c}\text { Average } \\
\text { acceptance* }\end{array}$ \\
\hline 1 & Coca-Cola Airline & 5.16 \\
\hline 2 & Kellogg's microwave dinners & 4.71 \\
\hline 3 & Coca-Cola beer & 4.68 \\
\hline 4 & Yamaha Internet shop & 4.62 \\
\hline 5 & Benetton magazine & 4.45 \\
\hline 6 & Kellogg's hotel chain & 4.14 \\
\hline 7 & Yamaha furniture & 3.62 \\
\hline 8 & Benetton chewing gum & 3.36 \\
\hline 9 & Benetton electronic devices & 3.00 \\
\hline 10 & Yamaha sunscreen & 2.62 \\
\hline 11 & $\begin{array}{l}\text { Coca-Cola computer } \\
\text { hardware }\end{array}$ & 2.56 \\
\hline 12 & Kellogg's bicycle & 2.00 \\
\hline
\end{tabular}

$*$ Maximum $=7$

Out of the 12 fictitious brand extensions in this study, six extensions reach an average acceptance that lies above the scale-mid-point of 4 , a score we considered relatively high. These extensions are Coca-Cola Airline; Kellogg's microwave dinners; Coca-Cola beer; Yamaha internet shop; Benetton magazine; and Kellogg's hotel chain.

From the ranking, one can draw some interesting conclusions. Coca-Cola, which we have defined as a highly symbolic brand, scored high in two out of three extension cases. The success of the Coca-Cola airline clearly illustrates how far a symbolic brand in fact can be stretched if the extension shares certain symbolic associations such as "fun" and "youth". These associations also play an important role in the evaluation of the brand's 
extension to beer. In the first part of this research it was found that symbolic and quality associations had a positive impact on respondents' evaluation of Coca-Cola beer, whereas product-specific associations with Coca-Cola as a soft drink had a rather negative impact. The impact of various associations on the acceptance of brand extensions is illustrated in Table 3. The extension to Coca-Cola computer hardware scored very low in average acceptance. The reason is that no symbolic associations could be transferred to the extension product. Besides, product-specific associations were of no benefit to the extension either, as most respondents felt that Coca-Cola has no expertise in the area of computer equipment.

Table 3

The impact of various associations on the acceptance of brand extensions

\begin{tabular}{|c|c|c|c|c|}
\hline \multicolumn{3}{|c|}{$\begin{array}{l}\text { Product-specific } \\
\text { associations }\end{array}$} & \multirow[t]{2}{*}{$\begin{array}{c}\text { Quality } \\
\text { associations }\end{array}$} & \multirow[t]{2}{*}{$\begin{array}{c}\text { Symbolic } \\
\text { associations }\end{array}$} \\
\hline & $\begin{array}{l}\text { Product-category } \\
\text { associations }\end{array}$ & $\begin{array}{l}\text { Product-attribute } \\
\text { associations }\end{array}$ & & \\
\hline Coca-Cola Beer & Negative & Negative & Positive & Positive \\
\hline $\begin{array}{l}\text { Coca-Cola } \\
\text { Computer } \\
\text { Hardware }\end{array}$ & Negative & n.a. & Positive & n.a. \\
\hline Coca-Cola Airline & n.a. & n.a. & Positive & Positive \\
\hline $\begin{array}{l}\text { Benetton } \\
\text { Chewing Gum }\end{array}$ & n.a. & Negative & Negative & n.a. \\
\hline Benetton Magazine & Positive & n.a. & Negative & Positive \\
\hline $\begin{array}{l}\text { Benetton } \\
\text { Electronic Devices }\end{array}$ & Negative & n.a. & Negative & n.a. \\
\hline Yamaha Furniture & n.a. & n.a. & Positive & n.a. \\
\hline $\begin{array}{l}\text { Yamaha } \\
\text { Internet Shop }\end{array}$ & Positive & n.a. & Positive & n.a. \\
\hline Yamaha Sunscreen & n.a. & Negative & Positive & n.a. \\
\hline $\begin{array}{l}\text { Kellogg's } \\
\text { Microwave Dinners }\end{array}$ & Positive & n.a. & Positive & Positive \\
\hline Kellogg's Bicycle & n.a. & n.a. & Positive & Negative \\
\hline $\begin{array}{l}\text { Kellogg's } \\
\text { Hotel Chain }\end{array}$ & Positive & Positive & Positive & Positive \\
\hline
\end{tabular}

The case of Benetton shows similar results. The Benetton magazine lies in the upper half of the average acceptance score, with an average score of 4.45 out of 7 . In this case again, symbolic associations with the brand name Benetton were of high value to the perception of the magazine. For example, one-third of the respondents interviewed said that they could imagine Benetton would launch an interesting magazine, because the idea fits with the company's current image. This image was mainly expressed in symbolic terms, e.g. with the name Benetton being described as "controversial", "provocative", and "expressive". These symbolic associations are the reason why respondents could imagine a Benetton magazine to be 'interesting' and 'different'. As far as the other two Benetton extensions are concerned - chewing gum and electronic devices - symbolic as well as other associations 
failed to convince respondents of the products' value.

Regarding Yamaha, the brand was defined as primarily a functional brand in this study. According to our proposition, Yamaha should therefore face difficulties in stretching its brand into product categories that are very different from the brand's current product range. Table 2 basically supports this notion. The Yamaha Internet Shop ranked relatively high in average acceptance (average $=4.62$ ). This success, however, can be attributed to the positive impact of both product-specific and quality associations with the brand name Yamaha. Symbolic associations, which are non-existent or at least of minor importance in the case of Yamaha, basically had no impact on respondents' perception of the brand extension. For the other two extension cases, Yamaha furniture and Yamaha sunscreen, productspecific associations with Yamaha had a rather negative impact on the extensions, while symbolic associations again played no role. Both products ranked low in average acceptance.

Kellogg's extensions proved to be successful in two out of three cases. The success of Kellogg's microwave dinners is mainly attributable to the product's fit with Kellogg's existing product range of breakfast cereals and other food products. Kellogg's associations with 'good food' also had a positive effect on respondents' evaluation of the Kellogg's hotel chain; about one half of the respondents mentioned that they would expect a hotel with the name Kellogg's to serve a good breakfast and food in general. In addition to these associations, however, respondents mentioned that symbolic and emotional associations such as Kellogg's as a 'family-brand' with a 'friendly', 'healthy' and 'clean' image also played a major role in their evaluation of the Kellogg's hotel chain. Finally, regarding Kellogg's extension to a bicycle, both product-specific and symbolic associations failed to positively impress respondents, which is indicated by the product's extremely low acceptance score (2.00).

The results in Table 2 may be summarised as follows. Out of the six extension products that were most successful in terms of their average acceptance by respondents, only two products
- Kellogg's microwave dinners and Yamaha internet shop - ranked high as a direct consequence of their product-specific fit with the brands' original products. The remaining four extensions - Coca-Cola airline, Coca-Cola beer, Benetton magazine, and Kellogg's hotel chain - turned out to be more (relatively) highly accepted because they all share some symbolic brand beliefs or associations with the parent brand, and therefore have a certain degree of fit with the concept of the brand. The brand and the extension share something at the very basic level of values, such as "fun" in the case of CocaCola, "controversy" in the case of Benetton, or "family" and "healthy" in the case of Kellogg's. These shared values seem to have a strong positive impact on consumers in the evaluation process of a brand extension.

Conversely, extensions that were poorly accepted by the respondents of this study, e.g. Coca-Cola computer hardware, Kellogg's bicycles, or Yamaha sunscreen, miss any factor of fit with the brand's core products. Although some of the products are in fact extensions of symbolic brands, i.e. Coca-Cola and Benetton, the extensions fail to fit with the brand's image on a symbolic level. Yamaha, as the only functional brand in this study, proved successful in its extension to an internet shop. However, the brand could not be stretched into product categories that are further away from Yamaha's existing product range (the Internet Shop fits with Yamaha's existing product range because it is associated with electronics, technology, etc). The brands in this study that possess symbolic value, i.e. Coca-Cola, Benetton, and Kellogg's, on the other hand, can apparently be stretched far into quite unrelated product categories (e.g. an airline for Coca-Cola, a magazine for Benetton, and a hotel chain for Kellogg's) if the extension products fits with the brand's image on a symbolic level. Hence, we find support for Proposition 1.

Proposition 2 suggests that having a large number of products affiliated with a brand has a positive effect on consumers' evaluations of further extensions of that particular brand. The rationale for this proposition is that a strategy of successive extensions increases the amount and diversity of brand associations, reduces the 
effect on subsequent extensions and thus broadens the domain for future extension opportunities. Furthermore, increased investment by a company in a brand heightens consumer confidence in the brand.

Considering the brands examined in this study, Yamaha certainly stands out as the one brand that has been largely extended in the past. Starting off with the production of musical instruments, Yamaha has over the years extended its product range into motorcycles, motorboats, tennis racquets, electronic devices, etc. Coca-Cola, in contrast, has focused more on line extensions, e.g. introducing Coke Light, Cherry Coke, etc. Moreover, the company sells glasses, ashtrays, etc. displaying the Coca-Cola logo. These products, however, may be regarded rather as core product accessories than actual brand extensions. Kellogg's has developed various line extensions of its core product corn flakes, such as Kellogg's All Bran, etc. Besides, Kellogg's has introduced brand extensions in the food market, selling products such as bread crumbs.

Summarising, Yamaha is the one out of the four brands that consumers clearly associate with a diversified product portfolio. When the respondents of the study were asked about their associations with Yamaha, they typically mentioned various products, most frequently motorbikes, but also music instruments and electronic devices such as CD players. Concerning Benetton, one in four respondents - mostly males - associated the brand name with Formula 1 Racing. In contrast, no respondent associated Kellogg's with bread crumbs or any food products other than cereals.

In order to examine what effects the mere existence and the nature of previous brand extensions have on consumers' evaluations of a new brand extension, respondents were asked the following question (example): "Does the fact that Kellogg's has already extended its brand into categories other than its core product (bread crumbs, etc.) increase your acceptance of a new extension to Kellogg's Microwave Dinners?"

Respondents were asked to give their answer on a scale from one to seven. As with previous questions, marking 'one' indicated "definitely NO”, marking seven indicated "definitely
YES”. The means of the results were calculated, and are presented in Table 4.

Table 4

Ranking of average acceptance increases as a result of previous extensions

\begin{tabular}{|c|l|c|}
\hline Rank & Brand extension & $\begin{array}{c}\text { Average acceptance } \\
\text { increase as a result } \\
\text { of previous } \\
\text { extensions* }\end{array}$ \\
\hline 1 & $\begin{array}{l}\text { Yamaha internet } \\
\text { shop }\end{array}$ & 4.6 \\
\hline 2 & Yamaha furniture & 4.1 \\
\hline 3 & $\begin{array}{l}\text { Kellogg's micro- } \\
\text { wave dinners }\end{array}$ & 3.5 \\
\hline 4 & Benetton magazine & 3.0 \\
\hline 5 & Coca-Cola airline & 2.7 \\
\hline 6 & Coca-Cola beer & 2.6 \\
\hline 7 & $\begin{array}{l}\text { Benetton chewing } \\
\text { gum }\end{array}$ & 2.6 \\
\hline 8 & $\begin{array}{l}\text { Benetton electronic } \\
\text { devices }\end{array}$ & 2.6 \\
\hline 9 & Kellogg's hotel chain & 2.2 \\
\hline 10 & $\begin{array}{l}\text { Coca-Cola computer } \\
\text { hardware }\end{array}$ & 2.2 \\
\hline 11 & Yamaha sunscreen & \\
\hline 12 & Kellogg's bicycle & \\
\hline
\end{tabular}

* Maximum $=7$

Table 4 illustrates in a quantitative way what impact the existence and the nature of previous brand extensions have on the acceptance of the new brand extensions. In all extension cases, the average score indicates some form of increased acceptance, as all average scores lie above 1 (= definitely no increase in acceptance). However, only the four cases considered noteworthy are discussed (that is those cases with a mean score above 3.0). As the ranking shows, the positive effect of previous brand extensions was strongest for the Yamaha internet shop (4.6), and the Yamaha furniture (4.1). Regarding the internet shop, one in every three respondents said that they would consider making purchases via the Yamaha internet shop because they saw a clear link between the name Yamaha and "electronics" or "technology". 
Similarly, one in five respondents could associate furniture with the name Yamaha, because it is "related to music instruments like pianos". The case of Kellogg's microwave dinners is also interesting. None of the respondents mentioned bread crumbs or any Kellogg's food product other than cereals as associations with the name Kellogg's. Many seemed to be unaware that these products existed. However, when asked whether the fact that Kellogg's has actually extended its brand into products that are somewhat related to "dinner" (i.e. bread crumbs), would increase their acceptance of Kellogg's microwave dinners, the response was on average very positive.

In the cases of all three extensions discussed above (Yamaha internet shop, Yamaha furniture, and Kellogg's microwave dinners), the aspect of "trust in the company and the quality of its products" also played an important role. Especially in the case of Yamaha, numerous respondents said that they would buy the extension product(s) because "they have made good experiences" not only with the brand's core products, but also with different extensions of the brand. Consequently, previous brand extensions that were of good quality have heightened consumer confidence in Kellogg's and especially in Yamaha.

The fourth case of the Benetton magazine also shows how associations with a brand extension can help introduce a subsequent brand extension. Especially the male respondents associated Benetton with Formula 1 Racing. These associations were transferred to the extension of a magazine. As a result, some respondents would be more inclined to buy a Benetton magazine because they find the thought of Formula 1 being discussed in the magazine appealing.

The above results indicate that previous extensions of a brand do indeed have an influence on consumers' evaluations on brand extensions. If previous extensions and their associations are relevant (and positive) to the new extension (e.g. in the cases of Yamaha internet shop and Yamaha furniture), consumers on average are more likely to purchase the new brand extension. Moreover, successful brand extensions are likely to increase consumer confidence in the brand, and thus facilitate the introduction of new brand extensions. The results of this study support Proposition 2.

In our study, we were not only interested in when and whether a certain brand extension may be launched successfully. In addition to that, we intended to keep in mind the danger of brand dilution, i.e. the risk that a brand extension may eventually damage the original brand name by creating undesirable beliefs, or by diluting beliefs that have originally been associated with the parent brand.

As an indicator for brand dilution, respondents were asked whether a certain brand extension would change their attitude towards or image perception of the original parent brand. On a scale from -5 to 5 , respondents could indicate a negative change ( -5 to -1$)$, no change $(0)$, or a positive change $(+1$ to +5$)$. Subsequently, they were asked for reasons why they marked a certain number. Negative changes were used as an indicator for the risk of brand dilution. Table 5 illustrates how respondents' attitudes towards the brands were changed as a result of introducing various brand extensions.

Of the twelve extensions, four were subject to a significant risk of brand dilution. It was decided to consider the risk significant if more than one-fourth ( 25 per cent) of the respondents indicated a negative change in attitude triggered by the extension. Coca-Cola's extension to beer showed the highest risk of brand dilution, with 10 out of 25 respondents ( 40 per cent) marking a negative number on the scale. This is particularly interesting because Coca-Cola beer also ranks as the third most highly accepted brand extension out of all twelve extensions discussed in this study. In other words, consumers are interested in buying the CocaCola beer - at least once to try it out - at the same time, however, many of them regard the extension as a somewhat negative step by CocaCola, admitting that it may influence their perception of Coca Cola negatively. When asked for reasons for this reaction, respondents quite consistently replied that an alcoholic beverage like beer does not fit with Coca Cola's existing product range of "pure" soft drinks. Coca Cola 
would lose its image as "everybody's drink", as an "energizer for sportive people", as an "innocent" drink for the entire family, were some of the individual responses. This indicates that Coca Cola beer may cause brand dilution not only because it weakens existing associations (Coca Cola is clearly associated with soft drinks as opposed to alcoholic drinks), but also because the extension to beer may create new associations that are undesirable from a moral viewpoint (e.g. alcohol is unhealthy and "bad", especially for children).

The second highest risk of brand dilution (38 per cent) was found for Yamaha sunscreen lotion, which, in contrast to Coca Cola beer, also scored very badly on the average acceptance ranking (third last of all twelve extensions, see Table 5). Reasons for respondents' negative attitude changes were rather different from those of Coca Cola beer. Respondents mentioned that the idea of Yamaha sunscreen was "far fetched" and "strange", and "entirely unrelated" to what Yamaha's current focus is on (i.e. motor bikes, electronics, music instruments and sport equipment). Respondents felt that Yamaha has no experience in cosmetics, and they would wonder why Yamaha moves into that direction when the company "is so good at producing other things". These answers indicate a sort of confusion amongst consumers regarding the image Yamaha wishes to convey.

Similar reasons were given by respondents that were asked about the Kellogg's bicycle, which had the third highest risk of brand dilution, with six out of 21 respondents ( 29 per cent) indicating a negative attitude change toward Kellogg's. Respondents replied that an extension deviating so much from the company's existing product range would "disturb the clear image of Kellogg's as a cereal producer", and it would look as if Kellogg's has "lost interest in its core product". Apparently, Kellogg's associations with breakfast cereals are so strong that an extension to a completely unrelated product would lead to confusion, disappointment, and eventually to a more negative image perception of Kellogg's amongst certain consumers.

The final case indicating a significant risk of causing brand dilution in our study was the case of Benetton chewing gum. Six out of 22 respondents (27 per cent) marked a negative attitude change toward Benetton as a result of the extension to chewing gum. Certain respondents argued that in addition to a lack of fit between chewing gum and the company's existing products range, chewing gum was a product that is "small and easy to produce", or, in other words, an "inferior good compared to clothes". Thus, respondents expressed their disappointment about a global company like Benetton not "doing something bigger than chewing gum". Not only would such an extension fail to make any impression on certain consumers, but also it even runs the risk of harming Benetton's image.

The results indicate that the risk of brand dilution is a factor that marketers should consider with great care when launching a new brand extension. In our study, three types of products were at risk of damaging the company's original brand name. First, products that are reprehensible from a moral viewpoint - such as Coca-Cola beer - can cause brand dilution. Second, extensions triggering associations that are strongly at odds with existing brand associations may confuse and irritate the consumer. Consequently, they may damage the original brand name. Examples from our study are Yamaha sunscreen and the Kellogg's bicycle. Finally, brand extensions that consumers regard as "small" or "easy to produce" may also be the cause of brand dilution. This is demonstrated in this study by the example of Benetton chewing gum.

These results are in line with Proposition 3. All four previously discussed brand extensions trigger associations that are at odds, or do not fit, with the parent brands' original associations. Although Coca-Cola beer fits with the parent brand in that it is part of the same broad product category (beverages) and in that certain symbolic associations with Coca-Cola may be shared by the extension to beer (e.g. associations with parties and fun), one main factor appears to be responsible for a strong risk of diluting the Coca-Cola brand: beer is an alcoholic beverage. This in turn is, for a significant number of respondents in this study, incompatible with Coca-Cola's existing associations as a soft drink producer. Hence the risk of the Coca-Cola brand being diluted by the extension. 
Table 5

Changes of attitude towards the parent brand triggered by extensions

\begin{tabular}{|c|c|c|c|c|}
\hline $\begin{array}{l}\text { Change in attitude } \\
\text { towards } \\
\text { Brand parent } \\
\text { Extension brand }\end{array}$ & $\begin{array}{l}\text { Positive attitude } \\
\text { change triggered } \\
\text { by extension } \\
\text { (No. of } \\
\text { respondents) }\end{array}$ & $\begin{array}{l}\text { No attitude } \\
\text { change triggered } \\
\text { by extension } \\
\text { (No. of } \\
\text { respondents) }\end{array}$ & $\begin{array}{l}\text { Negative attitude } \\
\text { change triggered } \\
\text { by extension / } \\
\text { Brand Dilution (No. } \\
\text { of respondents) }\end{array}$ & $\begin{array}{l}\text { Negative attitude } \\
\text { change triggered } \\
\text { by extension / } \\
\text { Brand Dilution } \\
\text { (\% of respondents) }\end{array}$ \\
\hline Coca-Cola beer & 4 & 11 & 10 & $40 \%$ \\
\hline Yamaha sunscreen & 4 & 9 & 8 & $38 \%$ \\
\hline Kellogg's bicycle & 4 & 11 & 6 & $29 \%$ \\
\hline $\begin{array}{l}\text { Benetton chewing } \\
\text { gum }\end{array}$ & 4 & 12 & 6 & $27 \%$ \\
\hline $\begin{array}{l}\text { Kellogg's } \\
\text { microwave Dinners }\end{array}$ & 6 & 11 & 4 & $19 \%$ \\
\hline $\begin{array}{l}\text { Coca-Cola } \\
\text { computer hardware }\end{array}$ & 8 & 13 & 4 & $16 \%$ \\
\hline Yamaha furniture & 5 & 13 & 3 & $14 \%$ \\
\hline Benetton electronics & 8 & 12 & 2 & $9 \%$ \\
\hline Coca-Cola airline & 14 & 10 & 1 & $4 \%$ \\
\hline $\begin{array}{l}\text { Yamaha internet } \\
\text { shop }\end{array}$ & 12 & 8 & 1 & $5 \%$ \\
\hline Kellogg's hotel chain & 10 & 11 & 0 & $0 \%$ \\
\hline Benetton magazine & 9 & 13 & 0 & $0 \%$ \\
\hline
\end{tabular}

\section{8}

\section{Conclusions and implications}

The explorative and qualitative nature of this research led to an extensive discussion of the findings in order to attend appropriately to the propositions that guided the research. From another perspective, we also considered an extensive discussion beneficial to comprehend the complexity of brand associations as a means to extend brands. We are of the opinion that marketers can only have a thorough understanding of brand associations and their impact on brand extensions if they have a clear understanding of the psychological considerations that guide respondents towards the perceptions and preferences they hold about brand associations. Consumer psychology, which underpins these considerations, is subjective and, as such, complex and difficult to quantify. However, these aspects of consumer psychology impact strongly on respondents' buying decisions. Marketers, who comprehend the complex networks of associations related to a brand name, can exploit such knowledge as a powerful tool in marketing. In essence, the knowledge of how respondents perceive a particular brand - both in functional and in symbolic/psychological terms - may assist brand managers to successfully introduce a new brand extension. A deep understanding of how brand associations are transferred, could also prevent brand extension failures and minimise the risk of brand dilution.

Table 6 is a summary of the results gained from this empirical research study, and gives a short, structural evaluation of the three propositions tested in this study. 


\section{Table 6}

Summary of the main results of the study

\begin{tabular}{|l|l|}
\hline $\begin{array}{l}\text { Proposition } 1 \\
\text { Symbolic brands generally } \\
\text { allow for a wider stretching } \\
\text { than functional brands if the } \\
\text { extension product fits with } \\
\text { the brand image on a } \\
\text { symbolic level. }\end{array}$ & $\begin{array}{l}\text { Proposition supported by study results } \\
\text { Out of the six most highly accepted brand extensions in this study, four were } \\
\text { highly accepted because they share symbolic brand beliefs or associations } \\
\text { with the parent brand. These associations indicate that symbolic brands may } \\
\text { be stretched into rather unrelated product categories. } \\
\text { Example: Kellogg's hotel chain, Coca-Cola beer } \\
\text { It is more difficult to stretch primarily functional brands such as Yamaha, as } \\
\text { they need physical product similarity to be accepted. } \\
\text { Example: Yamaha sunscreen, Yamaha furniture }\end{array}$ \\
\hline $\begin{array}{l}\text { Proposition } 2 \\
\text { Having an increased number } \\
\text { of products affiliated with a } \\
\text { brand has a positive effect on } \\
\text { consumers' evaluations of a } \\
\text { new extension of the brand. }\end{array}$ & $\begin{array}{l}\text { Proposition supported by study results } \\
\text { If previous extensions and their associations are relevant and positive to the } \\
\text { new extension, consumers are more likely to purchase the new brand } \\
\text { extension. Moreover, successful brand extensions are likely to increase } \\
\text { consumer confidence in the brand, and thus facilitate the introduction of new } \\
\text { brand extensions. } \\
\text { Examples: Yamaha internet shop, Benetton magazine }\end{array}$ \\
\hline $\begin{array}{l}\text { Proposition } 3 \\
\text { If associations consumers } \\
\text { have with a brand extension } \\
\text { are at odds with what they } \\
\text { associate with the parent } \\
\text { brand, the risk of brand } \\
\text { dilution is high. }\end{array}$ & $\begin{array}{l}\text { Proposition supported by study results } \\
\text { In this study, three types of brand extensions were at risk of damaging the } \\
\text { company's original brand name: } \\
\text { Brand extensions that are strongly at odds with existing brand associations } \\
\text { (they may confuse or irritate consumers) } \\
\text { Examples: Yamaha sunscreen, Kellogg's bicycle } \\
\text { Brand extensions that are reprehensible from a moral/cultural viewpoint. } \\
\text { Example: Coca-Cola beer } \\
\text { Brand extensions that consumers regard as "small" or "easy" to produce. } \\
\text { Example: Benetton chewing gum }\end{array}$ \\
\hline
\end{tabular}

Respondents have certain associations and beliefs about a brand. These play an important consideration when marketers consider the extension of a brand because the transfer of such associations and beliefs about a brand could be negative. In such an event, the transfer will be unsuccessful. Product-category, productattribute, quality and symbolic associations could be relevant in this regard. Nevertheless, it seems that the higher/better the perceived fit between the original product and the brand extension, the higher the likelihood of acceptance of the extension by the target market. It is important to remember that perceived fit is not limited to physical or functional product similarity; the fit can also be on the symbolic level. Two findings also became clear in this study, namely the influence of symbolic brands and previous positive extensions on brand extensions. Firstly, symbolic brands lend themselves to be stretched wider than functional brands as long as the extension product(s) fit the brand image of the symbolic brand. The second result is that previous positive extensions of the brand also contribute to the acceptance of a new brand extension.

The importance of harmony between the parent brand and the brand extension also featured in our study. We identified three types of brand extensions to be risky (although it is only in respect of some of the brands studied), namely those that:

- are in contrast with existing brand associations,

- are reprehensible from a moral cultural viewpoint, and

- are regarded as "small" and "easy" to produce.

Brand extensions undoubtedly offer many advantages when a new product is launched. On the other hand, a certain amount of risk is always present in such situations. Although there seems to be an acceptable "distance" from the original/ 
core brand, brand managers should scrutinise all the dimensions of a brand that might benefit/ detract from an extension. "Distance" will, of course, also be influenced by the type of product/service in question.

A suggestion for future research would be to turn our propositions into hypotheses and subject them to large-scale quantitative studies. This could support or discredit the typology of associations established in this study.

\section{References}

1 AAKER, D.A. (1990) "Brand extensions: the good, the bad, and the ugly", Sloan Management Review, 31(4):47-56.

2 AAKER, D.A. \& KELLER, K.L. (1990) "Consumer evaluations of brand extensions", Journal of Marketing, 54(January):27-41.

3 AAKER, D.A. (1991), Managing Brand Equity: Capitalizing on the Value of a Brand Name, The Free Press: New York.

4 AAKER, D.A. \& JACOBSON, R. (1994) "The financial information content of perceived quality", Journal of Marketing Research, 31(May):191-201.

5 AAKER, D.A. (1996a) Building Strong Brands, The Free Press: New York.

6 AAKER, D.A. (1996b) "Measuring brand equity across products and markets", California Management Review, 38(Spring):102-120.

7 AAKER, J.L. (1997), "Dimensions of brand personality", Journal of Marketing Research, 34(August):347-356.

8 ARKEN, A. (2002) "The long road to consumer understanding”, Marketing Research, 14(2):2931.

9 BHAT, S. \& REDDY S.K. (1998) "Symbolic and functional positioning of brands", Journal of Consumer Marketing, 15(1):32-43.

10 BOTTOMLEY, P.A. \& HOLDEN, S.J.S. (2001)

"Do we really know how consumers evaluate brand extensions? Empirical generalizations based on secondary analysis of eight studies", Journal of Marketing Research, 38(November): 494-500.

11 BRONIARCZYK, S.M. \& ALBA, J.W. (1994) "The importance of the brand in brand extension", Journal of Marketing Research, 31(May):214-228.

12 DACIN, P.A. \& SMITH, D.C. (1994) “The effect of brand portfolio characteristics on consumer evaluations of brand extensions", Journal of Marketing Research, 31(May):229242.

13 DELVECCHIO, D. (2000) "Moving beyond fit: the role of brand portfolio characteristics in consumer evaluations of brand reliability", Journal of Product and Brand Management, 9(7):57-471.

14 DOYLE, P. (1994) Marketing Management and Strategy, Prentice Hall: Hemel Hempstead International (UK).

15 FOURNIER, S. (1998) "Consumers and their brands: Developing relationship theory in consumer research", Journal of Consumer Research, 24(March):343-373.

16 GARDENER, B.B. \& LEVY, S.J. (1955) "The product and the brand", Harvard Business Review, 33(March-April):33-39.

17 GLYNN, M.S. \& BRODIE, R.J. (1998) "The importance of brand-specific associations in brand extension: further empirical results", Journal of Product \& Brand Management, 7(6):509-518.

18 KASPER, H.; STREPP, Y. \& TERBLANCHE, N.S. (2005) "An exploratory qualitative study of brand associations as a means for brand extensions : Part 1", South African Journal and Management Sciences, NS 8(3):272-286.

19 KASPER, H.; VAN HELSDINGEN, P. \& DE VRIES, W. (Jr). (1999) Services Marketing Management, John Wiley: Chichester.

20 KELLER, K.L. (1993) “Conceptualizing, measuring, and managing customer-based brand equity," Journal of Marketing, 57(January):1-22.

21 KELLER, K.L. (1998) Strategic Brand Management: Building, Measuring, and Managing Brand Equity, NJ Prentice-Hall: Upper Saddle River.

22 LOKEN, B. \& JOHN, B.R. (1993) "Diluting brand beliefs: when do brand extensions have a negative impact?", Journal of Marketing, 57(3):71-84.

23 LOW, G.S. \& LAMB, C.W. (Jr). (2000) “The measurement and dimensionality of brand associations", Journal of Product and Brand Management, 9(6):350-368.

24 MILEWICZ, J. \& HERBIG, P. (1994) "Evaluating the brand extension using a model of reputation building", Journal of Product and Brand Management, 3(1):39-47.

25 PARK, C.W.; MILBERG, S. \& LAWSON, R. (1991) "Evaluation of brand extensions: the role of product feature similarity and brand concept 
consistency", Journal of Consumer Research, 18(September):185-193.

26 PITTA, D.A. \& KATSANIS, L.P. (1995)

"Understanding brand equity for successful brand extensions", Journal of Consumer Marketing, 12(4):51-64.
27 SWAMINATHAN, V.; FOX, R.J. \& REDDY, S.K. (2001) "The impact of brand extension introduction on choice", Journal of Marketing, 65(October):1-15. 